УДК 81.33

https://doi.org/10.25076/vpl.37.01

Т.С. Башканкова

П.Н. Хроменков

Московский государственный областной университет

ВЕЖЛИВОСТЬ В ИНТЕРНЕТ ДИСКУРСЕ

Статья посвящена исследованию вежливости в Интернет пространстве. На современном этапе жсизни Интернет коммуникация приняла особую популярность. Активный рост количества мировых пользователей предопределяет растущий объем данного вида общения, который необходимо исследовать. А также выявить основные проблемы, затрудняющие развитию успешного общения. В частности, возникает необходимость подробного разбора нарушений правил вежливости. В качестве предмета исследования рассматриваются особенности соблюдения или несоблюдения правил вежливости Интернетпользователями. Материалом исследования послужили форумы, из которых было выбрано для анализа по три вопросно-ответных полилога. Практическая значимость работы состочт в том, что его материалы могут быть использованы на семинарских занятиях по теории диалога, этикета, прагматике, культуре речи $u$ стилистике. $B$ ходе исследования теоретически $u$ экспериментально было доказано, что существуют определенные разновидности агрессивного речевого поведения, мешающие успешной коммуникации, которые встречаются особенно часто и какие маркеры речевой агрессии для них характерны.

Ключевые слова: язык Интернета, вежливость, Интернеткоммуникаиия, сетевой этикет, Интернет-сообщества, культура речи, речевое поведение.

UDC 81.33

https://doi.org/10.25076/vpl.37.01

T.S. Bashkankova

P.N. Khromenkov

Moscow Region State University 


\section{POLITENESS IN THE INTERNET DISCOURSE}

The article is devoted to the study of politeness in the Internet. Presently, Internet communication has become particularly popular. Growing number of users determines the growing volume of this type of communication, which is to be investigated. It is also important to reveal the main problems that impede successful communication. In particular, there is a need for a detailed analysis of politeness violations. As a subject of research, the features of compliance or noncompliance with the rules of politeness by Internet users are considered. The material of the study is forums, from which three question-answer polylogues were selected for analysis. The practical significance of the work lies in the fact that its materials can be used in seminars on the theory of dialogue, etiquette, pragmatics, speech culture and stylistics. In the course of the study, it was theoretically and experimentally proved that there are certain types of aggressive speech behavior that interfere with successful communication, which are found especially often and which markers of speech aggression are characteristic of them.

Keywords: Internet language, politeness, Internet communication, network etiquette, Internet community, culture of speech, speech behavior.

\section{Введение}

Одной из ключевых проблем коммуникации является проблема взаимопонимания, адекватного восприятия и передачи информации и, следовательно, результативности коммуникации. Отсутствие понимания между коммуникантами может стать причиной неуспешного протекания процесса коммуникации. Как слушающий, так и говорящий должны следовать определенным принципам кодекса общения. Проблема правил и принципов, регулирующих общение, привлекала внимание многих ученых (П. Грайс, Р. Лакофф, Дж. Лич, П. Браун и С. Левинсон, Б. Фрейзер и др.). В результате был сформулирован целый ряд правил и конвенций, которые коммуникантам следует соблюдать для оптимального протекания коммуникации. Важнейшими правилами общения считаются Принцип Кооперации П. Грайса, 
Принцип Вежливости Дж. Лича и правила прагматической компетенции Р. Лакофф.

Вслед за понятием «вежливость» объектом специального изучения в лингвистике стало понятие «невежливость». В настоящее время понятия «агрессивное речевое поведение», «речевая агрессия», «вербальная агрессия», «коммуникативная агрессия», «словесная агрессия», «язык вражды», «словесный экстремизм» активно исследуются в рамках лингвоконфликтологии, юрислингвистики, прагмалингвистики, теории диалога.

Интернет-коммуникация на современном этапе жизни является одним из наиболее активных видов коммуникации. На сегодняшний день мировая аудитория пользователей сети Интернет составляет более четырёх миллиардов человек. Для того чтобы общение во Всемирной Паутине протекало гладко, без коммуникативных конфликтов и коммуникативных неудач, появился негласный свод правил поведения в сети Интернет сетевой этикет или нетикет. Столь активная вовлеченность людей в Интернет-общение определяет актуальность настоящего исследования.

\section{Материалы и методы}

Материалом исследования послужили следующие форумы: https://pikabu.ru, http://forum.kinozal.tv, https://www.linux.org.ru/, https://club.osinka.ru, http://articles.komarovskiy.net/privivki.html, http://www.cirota.ru/forum, http://vidnoeforum.com, http://www.woman.ru/forum/, https://kalakazo.livejournal.com, https://www.oculus.ru.

Из каждого из этих форумов для анализа было выбрано по три вопросно-ответных полилога.

Для достижения поставленной в данной работе цели использовался метод прагматического анализа (исследование целей, намерений, коммуникативных действий, особенностей речевого взаимодействия участников коммуникации в условиях той иной коммуникативной ситуации), метод дискурс-анализа.

\section{Результаты и обсуждение}

Речевое общение считается одним из первостепенных видов человеческой деятельности. Оно является предметом изучения многих научных дисциплин: лингвистики, социологии, 
психологии и др. В настоящее время вопросам межличностного взаимодействия уделяется особое внимание на площадке лингвистических исследований. Вежливость - это один из значимых элементов общения, обеспечивающие успешное и бесконфликтное его протекание.

Коммуникация может быть успешной или неуспешной. Успешная коммуникация - это адекватная коммуникация, при которой достигается более или менее полное, но обязательно достаточное, с точки зрения коммуникантов, взаимопонимание. Неуспешная коммуникация - это такая коммуникация, при которой возможны коммуникативный сбой, коммуникативный провал и еще одно явление - «коммуникативная неудача», являющиеся причиной недостаточного, с точки зрения коммуникантов, взаимопонимания. Среди факторов, обуславливающих адекватную коммуникацию, т.е. успешное ее протекание, нужно назвать определенную общность «знаний» коммуникантов.

Различие между успешной и неуспешной коммуникацией заключается в том, что для осуществления успешного общения необходимо учитывать несколько факторов, из которых наиболее важные: общий фонд знаний, накопленный опыт участников коммуникации, связь коммуникантов с определенной коммуникативной ситуацией, следование принципам Кооперации и Вежливости, верный выбор стратегий и тактик. Из-за несоответствия этих факторов (или одного из них) коммуникация может оказаться неуспешной.

В лингвистической литературе придается большое значение разработке теории вежливости, так как считается, что данная категория играет немалую роль в процессе коммуникации. Среди существующих концепций можно выделить такие трактовки вежливости как: «вежливость как социальная норма» (Б. Фрейзер), «вежливость как речевые максимы, правила» (П. Грайс, Р. Лакофф, Дж. Лич), «вежливость как «сохранение лица» (П. Браун и С. Левинсон), «вежливость как понятие дискурса» (Р. Уоттс).

Правил вежливости, обеспечивающих успешную коммуникацию, довольно много. Это и Принцип Кооперации П. Грайса, который в кратком виде гласит: сообщай столько информации, сколько требуется, не утаивай информацию; не 
сообщая ложной информации, не отклоняйся от темы, выражайся ясно и понятно (Грайс, 1985, с. 222). Это и принцип вежливости Дж. Лича, который, по мнению самого автора, дополняет Принцип Кооперации Грайса и призывает собеседников: будьте тактичны (уменьшайте затраты слушающего, увеличивайте выгоду слушающего), будьте великодушны (уменьшайте собственную выгоду, увеличивайте выгоду слушающего), одобряйте собеседника, хвалите его; будьте скромны; уменьшайте разногласия между вами и собеседниками, увеличивайте согласие; уменьшайте антипатию между вами и собеседниками, увеличивайте симпатию. Упомянем также одно из важных прагматических правил Робин Лакофф «Веди себя так, чтобы собеседнику было приятно, будь дружелюбным» (Lakoff, 1973, с. 303). Ряд авторов включал в число правил успешного общения также необходимость избегать иронии (ибо это дружелюбный способ оскорбления) и подтрунивания.

Важность соблюдения различных максим принципа Вежливости в процессе коммуникации не одинакова, как не одинаковы и характерные реакции реципиентов (слушающих) на эти нарушения. Нарушения максим Такта и Великодушия, Одобрения и Симпатии обычно вызывают резкую негативную реакцию собеседников. Напротив, нарушение максим Скромности и Согласия в большинстве ситуаций приемлемы и даже необходимы. Для коммуникации соблюдение принципа Вежливости не менее важно, чем соблюдение принципа Кооперации. Однако наибольшее значение имеет соблюдение максим Такта, Великодушия и Симпатии, которые в наименьшей степени связаны непосредственно с обменом информацией. Что же касается максим Согласия, Одобрения и Скромности, соблюдение которых может привести к серьезному искажению истинности информации, то эти максимы часто нарушаются коммуникантами ради соблюдения максимы Качества.

Если же правила и нормы ведения диалогического дискурса игнорируются слушающим и/или говорящим, принцип Вежливости не соблюдается, тогда участникам диалогического дискурса трудно достичь взаимопонимания, и можно предположить, что их двоих или кого-то одного из них постигнет коммуникативная неудача, т.е. коммуникация станет неуспешной. 
Понятие «невежливость» стало объектом специального изучения в лингвистике позже, чем понятие «вежливость». Существуют разные трактовки понятия «речевая агрессия». В частности, под речевой агрессией понимается «форма речевого поведения, нацеленного на оскорбление или преднамеренное причинение вреда человеку, группе людей, организации или обществу в целом» (Быкова, 1999, с. 96), т.е. имеется в виду речевой акт, замещающий агрессивное физическое действие: оскорбление (в том числе грубая брань), насмешка, угроза, враждебное замечание, злопожелание, категоричное требование без использования общепринятых этикетных средств и т.д.

Этикет играет важнейшую социальную роль в межличностном общении. Он позволяет находить общий язык и достойно воспринимать сложную ситуацию. Отказ от этикета ведет к ухудшению отношений между людьми и стирает нравственные ориентиры. В связи с этим придерживаться культурных норм следует всегда, вне зависимости от того, с кем и где вы общаетесь.

Сетевой этикет - это правила поведения, общения в Сети, традиции и культура Интернет-сообщества, которых придерживается большинство. Чаще всего под явным нарушением этикета понимают оскорбления и переход на личности, злонамеренный отход от темы (оффтопик), рекламу и саморекламу в не предназначенных для этого местах. Также нарушением этикета является клевета и иная злонамеренная дезинформация (обман) или плагиат.

Основными характеристиками виртуальной коммуникации является анонимность; создание «виртуальных личностей»; добровольность и желательность контактов; затрудненность эмоционального компонента общения; стремление к нетипичному, ненормативному поведению. Анонимность в акте коммуникации приводит к тому, что ряд барьеров общения теряет своё значение. Следствием этого может стать, с одной стороны, простота и раскрепощенность в общении, а с другой - своеобразная свобода высказываний и поступков, т. к. риск разоблачения и негативной оценки минимален. Кроме того, коммуникация в компьютерной сети способствует возрастанию коммуникативной открытости и толерантности. 
Фактически, правила поведения в Сети во многом схожи с этикетом в реальной жизни. Следовательно, многие нарушения имеют одинаковую природу.

Тема представляется нам чрезвычайно обширной и, поскольку мы находимся в рамках формального аппарата теории речевых актов, мы бы хотели ограничить свое исследование лишь одним типом речевого действия - вопросами. Мы опираемся на классификацию речевых действий Н.И. Формановской, которая выделяет: репрезентативы (сообщения); комиссивы (обязательства); директивы (побуждения); рогативы (вопросы); декларативы (объявления); экспрессивы (выражения эмоций) и контактивы (выражения речевого этикета) (Формановская, 1998).

В данной работе мы будем исследовать ситуации и причины успешного и неуспешного сетевого общения с точки зрения соблюдения/нарушения правил вежливости для вопросноответного сценария.

Успешным мы будем считать общение, если спрашивающий достиг своей цели - получил ответ на свой вопрос или, хотя бы, получил какую-то полезную информацию. И неуспешным - если цель спрашивающего не была достигнута - он так и не прояснил свой вопрос.

Исследуемый материал позволил нам выделить следующие нарушения правил вежливости, или разновидности агрессивного речевого поведения, которые мешают успешной коммуникации:

1. Прямые нападки на личность собеседника, когда негативное отношение адресанта к объекту высказывания выражается в прямой форме: адресант прямо обращается к собеседнику (использует местоимения «ты», «Вы» в совокупности с инвективами, или же в ответ на его реплику явным образом оскорбляет его). Например: «Ты лжешь, мерзавец!», «Чушь!», «Цитата типичного совка!», «Провокатор типичный!». Такое речевое поведение нарушает практически все правила вежливости, выделенные у классиков, и рассматривается при описании агрессивного речевого поведения.

2. Выражение пренебрежения, неуважения, превосходства по отношению к собеседнику без прямых нападок на его личность. Сюда мы относим неадекватные, «вредные» советы, имеющие пресуппозицией негативную, уничижительную оценку 
собеседника, реплики с позиции превосходства над собеседником. Также в рамках этого типа деструктивного коммуникативного поведения мы рассматриваем иронические замечания. Понятие «ирония» определяется как «форма высказывания, истинный смысл которого противоположен смыслу, напрямую выводимого из речевого оформления» (Большой толковый словарь русского языка, 2000, с. 75). Основная функция данной формы коммуникации - подчеркнуть негативное отношение адресанта к объекту высказывания в косвенной форме. Например, реплика «В пивняк «Яма» и можно домой» в ответ на вопрос, какие места лучше посетить в Москве. Здесь нарушаются Максимы Такта и Одобрения Дж. Лича.

3. Прямолинейность и бестактность. Здесь мы рассматриваем прямое, граничащее с грубостью, выражение своего мнения, заведомо неприятного собеседнику, под прикрытием «борьбы за истину». Специфика данной формы коммуникации состоит в том, что это неосознанная речевая агрессия, провоцируемая низким уровнем культуры коммуникантов. В качестве примера можно привести реплику «Простите за прямоту, может даже грубость но зажралась Ваша жена» в ответ на вопрос адресанта, как ему быть в ситуации, что его жена не хочет иметь детей. В данном случае мы имеем дело с нарушением максимы Такта Дж. Лича.

4. Нарушение Максимы Количества П. Грайса «Не говори того, для чего у тебя нет достаточных оснований».

5. Нарушение Максимы Релевантности П. Грайса, согласно которой пропозициональное содержание высказывания или реплики должно соответствовать глобальной теме дискурса;

6. Употребление ненормативной лексики.

Теперь хотелось бы обратить внимание на то, что, как известно, форумы бывают очень разными. Вероятность получить букет нарушений правил вежливости на каком-нибудь форуме футбольных фанатов, да ещё и закончить общение коммуникативной неудачей существенно больше, чем на форуме любителей животных, например.

Осознавая это, мы сознательно выбрали нейтральные форумы. За рамками обсуждения, с одной стороны, остались форумы, где естественно ждать максимально агрессивного общения, а с другой стороны, это, например, милые мамские форумы, где правила 
вежливости не нарушаются вообще и все реплики сводятся к «чмоко-чмоки», «держим за тебя кулачки».

Форум - это такое место в Интернете, где собираются люди, которых объединяет одно увлечение или идея, и общаются на интересующую их тему. Они помогают друг другу советами и подсказками, обмениваются жизненным опытом, поддерживают друг друга. Люди, общаясь между собой, знакомятся, выявляют общие интересы, высмеивают или наоборот поддерживают коллективно других. Люди ходят на форум с целью самовыразиться, поделиться реальным опытом и знаниями, что-то прорекламировать или продать, чтобы задать волнующий их вопрос.

Форум при большом сайте, сетевом портале или официальной страничке какой-нибудь популярной вещи из реала. Посетители сайта могут встретиться, обсудить интересующие их темы, спросить совета или попросить помощи. В рамках данного типа форумов мы выбрали 2 форума: https://pikabu.ru и http://forum.kinozal.tv.

Площадка https://pikabu.ru является ярким примером информационно-развлекательного сообщества, который занимает 24 место в рейтинге самых популярных блогов в России. Участники данного сайта могут прикреплять на страницах посты и комментарии, которые представляют из себя крупные древовидные дискуссии. Помимо текста к постам можно прикреплять гифки, видео, картинки и интернет-мемы, составляющие немалую часть контента. Основная аудитория данного форума - мужчины в возрасте от 18 до 24 лет, которые составляют $87 \%$ от общего числа зарегистрированных пользователей (1,2 млн. человек). Популярность форума раскручивается с большой скоростью, если обратиться к статистике. Крупнейшие представители русскоязычных СМИ, такие как «Первый канал», «Московский комсомолец», «Meduza» активно пользуются контентом форума «Пикабу ру».

Из форума при сайте https://pikabu.ru мы рассмотрели полилог (https://pikabu.ru/story/kuda_skhodit_v_moskve_esli_tyi_bich_667898 1\#comments)

(1) SwedshHouseMafia: Здравствуйте уважаемые Пикабушатины) 
Первый раз поеду в Москву, денег особо нет, но город посмотреть хочется. Можете написать топ 5 мест, куда надо обязательно сходить, и топ 5 мест куда можно, но не обязательно. И может поделитесь лайфхаками)) Спасибо.

(2) Manji: Ну вы же в первый раз! Красная площадь, Кремль, Охотный ряд, Александровский сад, Детский мир зайдите, там есть выход на крышу публичный, красивая панорама. Походите по улицам прилежащим, чтобы почувствовать атмосферу города. Потом в метро, осмотрите старые станции в центре столицы, насколько вас хватит.

(3) SwedshHouseMafia: Оoo, уважаю сестричка. А тройку на сколько брать если на три дня? Так примерно?

(4) mattahari: Покупай тройка, клади туда рублей 300 , хватит с лихвой. 38 рублей поездка.

(5) int.13h: В ЦДМ уже 50p на крышу:( Впрочем, деньги не страшные.

(6) Manji: Ой, ну 50p есть даже у бомжей в Москве:)

(7) profvideoru: Националь, Крокус сити Молл, Барвиха Лакшери виллидж, Третьяковский проезд, Сохо румс.

(8) Maxon4x4: А в Крокусе что посоветуете? В мае вот, например, ожидается Международная выставка инновационных технологий для мясного и молочного животноводства, свиноводства и птицеводства. Настоятельно рекомендуете посетить?))) А в Лухари Вилаж на что обратить внимание?))

(9) Hegge2: Как приедешь, там три вокзала. В квартале от Казанского, если на вокзал смотреть тогда справа, там пельменная. По крайней мере была в 1993 году, а больше в Москве я не был, и не жалею. Ещё можешь мента пнуть, в обезьяннике побываешь. Думаю, этого достаточно.

(10) Parafraz: Можно сходить на Арбат, к своим, там бичей больше, чем прохожих.

(11) mitek095: В пивняк "Яма" и можно домой.

(12) rada.com: Католический собор Непорочного зачатия на Малой Грузинской. С тех пор как его увидела, постоянно хожу, уже около 15 лет.

(13) Exlibris: В Магнит сходи, когда найдешь просрочку доставай телефон и начинай снимать, опционально вызвать ментов и подраться с охраной. 
(14) Vladiuha: Видел бичи тусуются на площади трёх вокзалов. Если хочется впечатлений, то можно на Садовод. А про вечернее Бутово тут и говорить нечего. И небольшой лайфхак: на метро дешевле ехать по карте Тройка.

(15) SwedshHouseMafia: Оoо я вижу ты кабан здоровый, тройка это как подорожник? И сколько надо поездок бл*ть на 3 дня, так примерно, можешь почувствовать?

(16) HollischenBiber: Не надо ленинградский, нам тут бичей хватает и без него.

(17) cizinka212: Ну, я первым делом пошла на ГЗ МГУ, потом на Красную Площадь, ГУМ, в зоопарк, а между всем этим делом понаблюдала московское метро.

(18) ComedianTos: Если получится, то потрать 1500 на Останкинскую башню, впечатлений на год вперёд.

(19) Dostoevsky123: Не ходи в Москву.

Несмотря на грубый тон высказываний некоторых участников данного полилогического дискурса, SwedshHouseMafia благополучно получил ответ на заданный им вопрос. Ему был предложен широкий список достопримечательностей города Москвы, куда он планировал совершить свою поездку (Реплики под номерами (2), (7), (17)). На контрасте, мы можем наблюдать реплики, где были допущены нарушения основных правил вежливости.

Реплика (9) - участник с ником Hegge2 дает неадекватный совет, имеющий пресуппозицией негативную оценку. В своем высказывании он умышленно насмехается над человеком, который нуждается в его помощи.

Реплика (10) - участник с ником Parafraz нарушает Максиму Одобрения по отношению к спрашивающему. Автор данной реплики открыто оскорбляет человека на публике, сравнивая его со спившимися, опустившимися людьми.

Реплика (11) - участник с ником mitek095 ярко выражает иронию в своем кратком ответе. Он не заинтересован помочь московскому туристу, поскольку на первом плане для него усмехнуться и ввести в заблуждение адресанта.

Реплика (13) - участник с ником Exlibris активно нарушает ту же Максиму Одобрения. Он дает бесполезные рекомендации гостю столицы, откровенно ухмыляясь. 
Реплика (15) - участник SwedshHouseMafia совершенно открыто нападает на личность собеседника. Мужчина использует ненормативную лексику для придания остроты своему ответу, тем самым, раздражая человека еще больше. Он всеми возможными способами пытается задеть чувства спрашивающего, что выходит за все рамки разумного.

Реплика (16) - участник с ником HollischenBiber подхватывает волну своих предшественников и нарушает Максиму Одобрения. Выразив пренебрежение, участник данной беседы демонстрирует свою некомпетентность и отсутствие такта, вежливости.

Реплика (19) - участник с ником Dostoevsky123 использует иронию. Этот языковой прием используется в качестве насмешки над спрашивающим. Ее скрытый смысл должен побудить человека отказаться от своего визита в мегаполис. Это говорит, в свою очередь, о негостеприимстве и озлобленности.

В ходе общения прямые нападки на личность собеседника встретились в 1 реплике, что составляет $5,2 \%$ от общего количества реплик, ненормативная лексика была употреблена в 1 реплике, что составляет $5,2 \%$ от общего числа реплик и пренебрежение, неуважение, превосходство по отношению к собеседнику - 6 раз (31,5\% от общего числа реплик в полилоге).

Характерными маркерами речевой агрессии в данном полилоге являются сленгизмы и варваризмы, такие как «бич», «пивняк», «мент», «пнуть», «обезъянник», «кабан здоровый».

Профессиональный форум - это клуб специалистов в чём-то, или пользователей чего-то. Цель - взаимопомощь, обмен опытом. Примерами могут служить софтовые форумы (участники которых обсуждают программное обеспечение), родительские (семейные) форумы, женские или медицинские форумы (или клубы по болезням и здоровому образу жизни). В качестве иллюстрации приведем форум при сайте https://www.linux.org.ru/, где обсуждаются вопросы компьютерного софта, тестирования какихнибудь устройств, и в целом вопросы науки (преимущественно математики) и высоких технологий.

Рассмотрим подробно полилог 2
(https://www.linux.org.ru/forum/general/14975513?lastmod=15572471 $15995)$ из данного сайта. 
(1) feniks: Как сделать swap в /dev/null? Возможно ли такое сделать на Ubuntu?

(2) RedEyedMan4: Отлей мне своего боярышника или чем ты там упарываешься.

(3) mord0d: Чувак, таких веществ не бывает! Это только сдвиг по фазе, причём серьёзный. Здесь психиатрия бессильна!

(4) Deleted: Может быть всё же тебе его просто отключить?

(5) feniks: Мне интересно можно ли запустить процесс, например, сервер варкрафата лал и убрать его в /dev/null и что после этого будет. Клиенты будут к нему коннектиться? Вообщем, экспериментирую, изучаю. Ну так что, можно?

(6) Maxbart: Ну попробуй.

(7) burato: У вас чё там каникулы что ли?

(8) feniks: Все майские с этой проблемой бьюсь, помоги!

(9) router: Нет, нельзя. Формально потому, что / dev/null символьное устройство, а не блочное. Ближе к реальности - у /dev/null нет размера, mkswap там не работает. А настоящая причина - даже если как-то всё это обойти, первая же попытка подгрузить страницу из такого «свопа», скорее всего, приведёт к kernel panic.

(10) feniks: Ты разбил мои мечты!

(11) router: Скорее всего, изнутри контейнера ты не видишь реальную ситуацию, и /dev/null фейк. Но утром на свежую голову почитаю подробнее, мало ли всякой фигни бывает в жизни.

(12) feniks: Тогда другой вопрос. Можно сделать так, чтобы запустить программу, а через указанное время послать в /dev/null, не убивая?

(13) router: Чё? Были проекты, которые позволяли запущенный процесс со всем содержимым памяти экспортировать в файл и, например, перенести на другой хост или временно «приостановить». Это ж блин проще простого.

(14) Woolf: Ты вообще знаешь, что такое /dev/null?

(15) anonymous: Только народными средствами такое и лечится... автору поможет стакан масла из семян подсолнечника перестанет этой дурью маяться. Для закрепления эффекта процедуру повторить.

(16) Avengerist: По-моему, это уже не лечится народными средствами... 
(17) BMX: Боярышник всёх дураков вылечит.

(18) anonymous: А ты понимаешь, что такое vps? Сходи почитай. И в VPS может так и отображаться swap реальной host системы.

(19) slamd64: Жжжесть, бл*. Я даже как-то стесняюсь спросить: «А зачем?».

(20) SevikL: Это не проблема. Вот весеннее обострение головушки - это проблема, которой стоило бы заняться.

(21) alexferman: В такой своп можно бесконечно выгружать страницы памяти))

(22) mord0d: Но никогда не иметь к ним доступа. Не думаю, что мне нужно объяснять тебе, каковы будут последствия. Впрочем, я уже расписал выше.

Рассмотрим какие реплики мы сочли нарушающими правила вежливости и почему. Участник с ником feniks просит совета у профессионалов с установкой своп на разных операционных системах. В ответ он получает развернутые примеры решения данной проблемы.

Реплики (2), (3) - участники с никами RedEyedMan4 и mord0d в своих высказываниях очень резки и бестактны. Они преднамеренно давят на психику спрашивающего, оперируя унизительной оценкой человека. В их словах прослеживается сарказм, который по своей природе является язвительной насмешкой.

Реплика (15) - участник с ником anonymous откровенно нарушает Постулат Одобрения, предложив человеку отказаться от своей идеи, совершенно грубым путем. Он публично оскорбляет адресанта, что противоречит всем законам любезности.

Реплики (16), (17) - авторами которых являются участники Avengerist, BMX, демонстрируют ущемление и унижение спрашивающего. Они активно продолжают агитировать его отступить, делая упор на его неадекватном состоянии.

Реплика (19) - участник slamb64 вплетает в свою речь ненормативную лексику. Эта вербальная агрессия умышленно может ранить и унизить человека, чего мужчина, возможно, добивается, начав свой разговор в таком негативном ключе.

Реплика (20) - участник SevikL поддерживает голос большинства, тем самым настаивая на самолечении адресанту. 
Этот некрасивый жест говорит о невоспитанности человека и его непросвещенности в вопросах этики.

Характерными маркерами речевой агрессии в данном полилоге являются слова и выражения с негативной оценкой умственных способностей адресанта («дурак», «сдвиг по фазе», «весеннее обострение головушки»), глаголы с прямой негативной оценкой («упарываешься», «дурью маяться»), акты иронии. Также участники обсуждения употребляют ненормативную лексику.

Персональный форум напоминает блог, но он пошире. Это некоторая форма общения, когда общение складывается вокруг лидера, одного или нескольких. Здесь мы будем анализировать полилог из форума доктора Комаровского http://articles.komarovskiy.net/privivki.html. Евгений Олегович Комаровский широко известен как ведущий телепередачи «Школа доктора Комаровского» и радиопрограммы «Микстура шоу», а также благодаря своим многочисленным научным трудам и книгам, например, «Здоровье ребёнка и здравый смысл его родственников». Его профессиональная деятельность, начавшаяся с реанимационного отделения Харьковской больницы, связана с педиатрией. Общепринятое признание доктор получил, разработав эффективную методику по уходу за ребёнком с учётом отечественной ментальности и современных условий развития. Она подробно представлена на платформе его форума http://articles.komarovskiy.net/privivki.html в формате видео, вопросно-ответных полилогов, в информационной библиотеке, где находится большое собрание книг и статей. Данный сайт существует уже более десяти лет и за этот немалый срок скопилась информация, которой активно продолжают пользоваться люди. Нами был отобран следующий полилог 3 (http://forum.komarovskiy.net/viewtopic.php?f=28\&t=28058\&sid=0f2 36793256a830ee0dff6223c3c47c3)

(1) ADAm: У дочери острый цистит. Ей 11 месяцев. Что посоветуете делать с прививками?

(2) Алекс: ADAm, лечите острый цистит, потом делаете прививки, если ничего против них не имеете.

(3) Helen: Только не раньше, чем через месяц после выздоровления. 
(4) Малинка: А если до года не делать прививки? Никто не знает после травмы головы, когда можно делать прививки?

(5) Мама_Аня: Есть какая-то на то причина или просто не делать?

(6) Малинка: В 6 мес. упал с дивана, лежали в больнице, щас нам 8мес.

(7) Оля: Малинка, с такими травмами вас наверняка должен был наблюдать как минимум невролог. Что он то говорит?

(8) Lirisha: У меня такой вопрос: нам невропатолог дал модотвод от прививок на 6 мес. и инфекционист на 3 месяца, а иммунолог с педиатром требуют начать ставить прививки или писать отказ. Правда предлагают начать с полиомиелита и гепатита, посмотреть, как пойдет, и ставить остальные. Что делать?

(9) Jitel: Lirisha, не совсем понятно. Что значит дали медотвод невропатолог и инфекционист, а иммунолог с педиатром требуют ставить прививки? Медотвод оформлен? Тогда какие могут быть вообще вопросы? У вас вообще нет никаких прививок? Как же ж так можно со своим ребенком.

(10) Lirisha: В карте есть запись инфекциониста и в карту вложен листок с консультацией невропатолога. Прививок у нас нет никаких, потому что мы очень рано родились, тяжело выхаживались, лежали на ИВЛ и болели менингитом. Местный иммунолог говорит, что инфекционист с невропатологом перестраховываются и прививки нужно делать.

(11) Nataly Koot: Lirisha, у нас была гораздо более легкая причина. То, что сейчас называется ПЭП, а тогда было записано в карте гипоксийно-травматическое поражение ЦНС. Тем не менее, до 10 месяцев у нас был медотвод от всего! Первая прививка была БЦЖ, в 10 мес. Я бы лично в вашей ситуации не спешила.

(12) Ната-Днепр: Мы перенесли менингоэнцефалит и сразу потом пневмонию. Иммунитет был никакой, кололи и капали иммуномодуляторы. Обл. иммунолог дала медотвод на 6 мес. без разговоров. А вот потом скоро срок подходит к концу. А что потом?

(13) IrinaMama: Уважаемые форумцы, посоветуйте, пожалуйста, что мне делать? Доче годик. А последняя АКДС с девяти месяцев не сделана. Две с половиной недели назад доча 
заболела, как сказала участковая ангиной. Участковая говорит, что это все ерунда и надо скорее делать прививку, а то предыдущие пропадут. Что делать?

У пользователя ADAm возник вопрос о необходимости прививок для маленькой дочери. Будучи неопытным в этой области, он ищет совет среди профессионалов, которые успешно дают краткий, но полезный ответ. Можно считать, что данный дискурс имеет благополучный результат.

Реплика (4) - участница Малинка нарушает Максиму Релевантности, поскольку ее вопрос эквивалентен заданному в теме. Она пытается направить суть разговора совершенно в другое русло, что противоречит правилам вежливости.

Реплика (8) - участница Lirisha пренебрегает той же Максимой, резко вступая в полилог со своим личным вопросом, который отличается от проблемы, которую стараются разрешить остальные пользователи.

Реплика (9) - участник Jitel в грубой форме обращается к своему собеседнику в поисках истины. У него своя правда, но ее подача нарушает Максиму Такта.

Реплики (12), (13) - участники Ната-Днепр и IrinaMama позволяют себе нарушить Максимы Релевантности. Заострив внимание только на своих проблемах, женщины игнорируют проблему человека, который к ним обратился.

Характерными маркерами речевой агрессии в данном полилоге являются глаголы с осуждающим значением («не надо ни по кому лазить»).

Клубный форум основан на общности взглядов на что-либо. Сюда следует записать большинство политфорумов, или книголюбов, или киноманов, или меломанов. Цель - просто приятное общение с единомышленниками. Например, форум https://www.oculus.ru/ предлагает пользователю ознакомиться с вопросами теоретической и прикладной астрологии, эзотерики и многих других соприкасающихся сфер знаний. Ядро основных участников сайта постоянно растёт в геометрической прогрессии, количество прочитанных статей и страниц превышает отметку 60 тысяч за сутки. Эти показатели свидетельствуют об активности форума, о том, что участники ежедневно оказывают друг друга взаимопомощь, обмениваются опытом и проводят свои обучения. 
(1) Sofial-Ylia: Получилось ли у кого-нибудь выйти замуж при управителе 7 дома Уран и ретроградном, а также аспекте оппозиции Венера Сатурн? Посмотрела сейчас соляр и нашла маленький шанс в этом году с мая, как вы считаете это возможно? Благодарна за Ваш ответ!

(2) zvezdny: Обязательно, выйдете замуж. Муж будет знатный и обеспеченный.

(3) Galaxyalex: A если институт брака отменят? Как тогда быть с вашим прогнозом?

(4) zvezdny: Женское естество во все времена хочет замуж, независимо от институтов. Против природы не попрешь.

(5) Galaxyalex: Вы забыли, что есть ещё и другая половина человечества. А патриархат и законы, устанавливаемые мужчинами, ещё никто не отменял.

(6) Seide: У меня получилось, но быстро развелась.

(7) Julianna: Вам не желательно заключать официальный брак, потому что, если он будет, будет развод, таков Уран, он обязательств не любит.

(8) April: К вам никто не проявляет внимание? Вам никто не нравится? Вам попадаются только женатые и прид*рки? У вас вообще не было отношений? Что именно не так?

(9) Sofia1-Ylia: Проблема в том, что длительное время встречаюсь с молодым человеком, который почему-то не рассматривает официальный брак...Его дата рождения 28.05.88г 3ч 50 мин.

(10) Galaxyalex: Собственно, и вам вопрос: как думаете зачем этому мальчику 1988 брак? Может приданное у вас какое-то хорошее.

(11) zvezdny: От этого МЧ предложения не дождетесь. В его карте заложен другой образ супруги.

(12) Sofia1-Ylia: Как хорошо, что Вы знаете так мой характер, и сразу делаете такие однозначные выводы))

(13) mir_tesen: Желание мужчины создать брак, особенно до 30 лет, обычно связано с особенностями его натуры, в гороскопе должно быть выделено то, что человек без отношений никак не может, плюс склонность придавать конкретную земную форму отношениям официальную. 
(14) Apri: Если у вас с ним не создается формула любви, то гражданский брак с ним так и не

Реплики (3), (4), (5) - участники с никами zvezdny и Galaxyalex с самого зарождения дискуссии попытались сбить с толку своих собеседников, вводя персональные вопросы. Они начали разговор на совершенно отличную, обобщенную тематику, не обратив внимания на исток данного полилога.

Реплика (8) - участница с ником Apri атаковала адресанта шквалом отстраненных вопросов, не несущих в себе какую-либо пользу. Это явный пример нерелевантности, что говорит о нарушении вежливости.

Реплика (10) - участник с ником Galaxyalex не оказав помощи, загружает девушку негативными мыслями о ее молодом человеке.

Реплики (11), (13), (14) - участники zvezdny, mir_tesen и Apri совершенно не следуют Максиме Релевантности. Содержание их ответов не отвечает запросу.

Характерными маркерами речевой агрессии в данном полилоге являются слова с ярко выраженной негативной оценкой, фактически составляющей их основной смысл в адрес одной из участниц беседы («дорогуша», «дамочка»), вдобавок несколько глаголов с негативной оценкой («развести сопли», «не загоняйтесь»). Также участник обсуждения употребляет ненормативную лексику.

Тем не менее, данный полилог можно считать успешным для Sofia1-Ylia, потому что она получила ответ на волнующий еe вопрос, вопреки нарушениям вежливости со стороны некоторых участников сложившейся беседы.

Форум без тематики, где участники обсуждают любую тему, и флуд на таких форумах, как правило, приветствуется. Примерами могут служить любые городские форумы, например форум портала города Видное http://vidnoeforum.com, где обсуждаются самые разные вопросы из жизни города: покупка жилья, новости спорта, медицина города, преподавание и т.п.

Форум http://vidnoeforum.com предназначен для благожелательного общения между жителями города Видное. Главная страница включает в себя список всех категорий форума и их разделов, помимо этого еще приводится статистика по каждому, включая количество тем и сообщений. Активный 
гражданин этого города может найти такие темы для обсуждения, как экологическая обстановка, внеуличный общественный транспорт, объединение администраций города и района в городской округ и многое другое. Что касается молодежи, то им предоставляются для дискутирования разные рубрики: кино и телевидение, музыка и артисты, мировой спорт, творчество и литература. Как мы видим, данный форум охватывает горожан всех возрастов.

Мы проанализировали полилог 4 (http://vidnoeforum.com/topic/13845-uplotnitelnaya-zastroyka-gorodai-rayona/) из данного форума.

(1) Добрый Чебурек: Как застройка влияет на город? Мне лично не нравится. Район ПЛК-советской в расчёт не берём, ибо по факту - это очередной район Москвы. Я говорю об активной застройке старой части города - втиснутый банк МК, храм, новые магазины, разрушенные 2-х этажки на строительной, преобразование Гаевской.. как вы к этому относитесь? По мне неприятно. Рушится самобытность города.

(2) AlexEf: Банк на площади очень хорошо вписался. Двухэтажки в центре, какое у них было состояние? Не уверен, что хорошее.

(3) Kemaly: Будем спальным районом 6))) Исходя из того, что квартиру мне все равно не купить:)) Причем негде:))) Я против:)) И так народу в городе много:)) А кто сюда поедут, черные?:)) Все порядочные люди уже с квартирами:))

(4) Kindly: Иногда прям ностальгия по-старому, не облагороженному городу...

(5) Doctor: Все снести нах*p и построить одну большую баскетбольную площадку!

(6) SestraHaos: Жильё строится без расширения соц. базы. Радоваться этому могут только недальноВидные дураки.

(7) Бука: На мой взгляд, уничтожение центральной части города - это преступление перед жителями города. Банк в центре города - это престиж для банка. Хотя сам банк теперь не рад этой затее. В принципе, он смотрится нормально, но вот строительство за баней новой пидростройки. Это комизм. Как только это у.....e многоэтажное туда уместится. Скоро наше банька будет не вписываться в городской ландшафт. 
(8) Юлёк: Да уж, мне кажется, что администрация не читает форум, как-то с трудом себе представляю товарища Голубева в форуме:D Хотя, наверное, много интересного бы узнал.

(9) Бука: Администрация читает, все равно на работе делать нечего.

(10) Добрый Чебурек: Вчера ещё какой-то памятник на вертолёте привезли!! Больше памятников хороших и разных!!!!:D УУууу, я пошёл...

(11) Josefina: Если бы хороших и нужных это другое дело, а то жутко надоел этот показушный, отстойный пафос! Прямо "пир во время чумы"!

Реплика (3) - участник с ником Kemaly открыто показывает свое неуважение и чувство само превосходства по отношению к людям отличной от его национальности.

Реплика (5) - участник c ником Doctor употребляет нецензурную лексику при ответе своему собеседнику.

Реплика (6) - участник с ником SestraHaos некрасивым образом обобщает часть граждан города Видное, которые имеют отличную точку зрения.

Реплика (7) - участник с ником Бука нарушает Максиму Одобрения, когда свободно выражает чувство негодования и раздражения с единицами ненормативной лексики.

Реплика (9) - с тем же участником представляет пример того, когда человек говорит о вещах, на которых у него нет достаточно информации. Данный прием может дезинформировать спрашивающего, что может привести к путанице в поставленном вопросе.

Реплика (11) - участница с ником Josefina пренебрежительно отзывается о сложившейся ситуации в городе.

Характерными маркерами речевой агрессии в данном полилоге представляются слова с выраженной негативной оценкой («черные», «пидростройки», «дураки»), также превалирует нецензурная лексика в словах участников.

\section{Выводы}

Нами были выделены следующие нарушения правил вежливости, которые не дают возможности организовать доброжелательную атмосферу среди собеседников: 1) прямые нападки на личность собеседника, 2) выражение пренебрежения, 
неуважения, превосходства по отношению к собеседнику без прямых нападок на его личность, 3) прямолинейность и бестактность, как неосознанную речевую агрессию, провоцируемую низким уровнем культуры коммуникантов, 4) безосновательные высказывания, 5) нерелевантные высказывания и 6) высказывания, содержащие ненормативную лексику.

Анализ показал, что чаще всего участники рассмотренных полилогов выражают пренебрежение, неуважение, превосходство по отношению к собеседнику без прямых нападок на его личность, используя иронию, а также инвективную лексику.

Специфическая аудитория православных форумов наиболее часто проявляет прямолинейность и бестактность. Также довольно часто встречаются нерелевантные сообщения. Прямые нападки на личность собеседника встречаются не слишком часто. Частично это обусловлено тем, что мы сознательно ограничили свое рассмотрение нейтральными форумами, оставив за рамками обсуждения форумы, где естественно ждать максимально агрессивного общения. Как видно из таблицы, прямая речевая агрессия встречается не на всех форумах.

Характерными маркерами языковой агрессии являются слова и выражения, содержащие экспрессивную негативную оценку поведения человека, свойств его личности («лошара», «идиот»), слова и выражения, обозначающие антиобщественную, социально осуждаемую деятельность («педофил», «жирный тролль»), зоосемантические метафоры, отсылающие к названиям животных и подчеркивающие какие-либо отрицательные свойства человека («курица», «клуха»), глаголы с осуждающим значением или прямой негативной оценкой («вляпались», «поливаете дерьмом»).

Ненормативная лексика встречается не слишком часто, возможно, вследствие того, что в настоящее время большинство форумов жестко модерируется.

\footnotetext{
Литература

1.Быкова О.Н. Речевая (языковая, вербальная) агрессия: Материалы к энциклопедическому словарю «Культура русской речи» // Теоретические и прикладные аспекты речевого общения. Красноярск: Изд-во КрасГУ, 1999. - Вып. 1(8). - С. 91-103.
} 
2.Грайс Г. П. Логика и речевое общение // Новое в зарубежной лингвистике. - Вып. 16. Лингвистическая прагматика. - М.: Прогресс, 1985. - С 222-223.

3.Формановская Н.И. Коммуникативно-прагматические аспекты единиц общения. М.: Ин-т р.я. им. А.С. Пушкина, 1998.

\section{References}

Bykova, O.N (1999). Rechevaia (iazykovaia, verbal'naia) agressiia: Materialy k entsiklopedicheskomu slovariu «Kul'tura russkoi rechi» [Speech (linguistic, verbal) aggression: Materials for the encyclopedic dictionary "Culture of Russian speech"]. In Theoretical and applied aspects of speech communication, (pp. 91103). Krasnoiarsk: Izd-vo KrasGU.

Grice, G.P (1985). Logic and Speech Communication. Novoe v zarubezhnoi lingvistike, 16, 222- 223.

Formanovskaya, N.I (1998). Kommunikativno-pragmaticheskie aspekty edinits obshcheniia [Communicative-pragmatic aspects of communication units]. Moscow: A.S. Pushkin. Institute.

УДК 81-114.2

https://doi.org/10.25076/vpl.37.02

И.И. Валуйцева

Д.А. Князьков

Московский государственный областной университет

\section{ФОНЕТИЧЕСКИЕ СПОСОБЫ ОФОРМЛЕНИЯ ТЕКСТА КАК ПРИЁМЫ РЕЧЕВОГО ВОЗДЕЙСТВИЯ ПЕСЕННОГО ДИСКУРСА (НА ПРИМЕРЕ КОМПОЗИЦИЙ КОНКУРСА ЕВРОВИДЕНИЕ ХХІ ВЕКА)}

B cтатье рассматривается значимость фонетических средств выразительности в песенных текстах композиций международного конкурса Евровидение. Актуальность данного исследования обусловливается большим интересом к изучению функционирования песенного дискурса. Сочетание вербального и невербального компонентов усиливает воздействие на адресата. В этом случае большую роль играют приёмы речевого воздействия, которые создают определённую атмосферу в 